\title{
THE EFFECT OF WORK MOTIVATION, WORK DISCIPLINE AND ORGANIZATIONAL CULTURE ON EMPLOYEE PERFORMANCE IN INDOMARET SHOP IN SOUTH SURABAYA
}

\author{
Alan Margia Hermawan ${ }^{1}$, Bayu Airlangga Putra², Mochammad Arif ${ }^{3}$ \\ alanmargia41@gmaill.com ${ }^{1}$, bayu.airlangga71@gmail.com², muchamad.arif@narotama.ac.id ${ }^{3}$ \\ Departement of Managemen, Faculty of Economic and Business, Narotama University, \\ Jl. Arief Rachman Hakim Street Number 51, Sukolilo, Surabaya. ${ }^{1,2,3}$
}

\begin{abstract}
This study aims to determine the relationship between work motivation, work discipline andculture organizationalon improving employee performance at the Indomaret store in South Surabaya. This research is a quantitative researcher. With a population of 62 respondents. Data collection techniques using interviews, observation and questionnaires. The data analysis used is validity test, reliability test,assumption classictest and multiple linear analysis test. The results of the study influence the work motivation, work discipline andculture organizationalon the performance of indomaret shop employees in south Surabaya. Shows that there is arelationship positive and significantof $\mathrm{F}$ test 253.257> 3.15 simultaneously. Partially work motivation $-0,501$ $<\mathrm{t} 1,670$ has no significant effect on employee performance, work discipline $0,795<\mathrm{t}$ table 1,670 has no significant effect on employee performance and organizational culture 19,861> t table 1,670 has a significant influence on employee performance.
\end{abstract}

Keywords: Work motivation, work discipline, organizational culture and employee performance

\section{INTRODUCTION}

Understanding Motivation is an encouragement or reason that becomes the basis of one's enthusiasm for doing something to achieve certain goals. The meaning of motivation can also be defined as all things that cause encouragement or enthusiasm in someone to do something. Understanding discipline that is obedient to applicable laws and regulations. According to JS Badudu and Sultan Muhammad Zein, discipline is organized, obedient, orderly, orderly. Discipline is also closely related to sanctions that need to be imposed on those who violate. Understanding Organizational Culture is a characteristic that exists in an organization and becomes the guideline of the organization so that it distinguishes it from other organizations. In other words,culture organizationalis a norm of behavior and values that are understood and accepted by all members of the organization and are used as a basis in the rules of behavior in the organization. Performance is work performance, which is a comparison between work results and set standards (Dessler, 2000: 41). Performance is the result of work both in quality and quantity that is achieved by someone in carrying out tasks according to the responsibilities given (Mangkunagara, 2002: 22).

\section{Research Question}

Based on the background of the researcher formulated the problem as follows :

1. Whether motivation has a significant effect partially on the performance of indomaret employees in south Surabaya?

2. Does the work discipline have a significant effect partially on the performance of indomaret employees in south Surabaya?

3. Whether organizational culture has a significant effect partially on the performance of indomaret employees in south Surabaya?

4. Whether motivation, work discipline and organizational culture have a significant effect simultanneously on the performance of indomaret employees in south Surabaya?

\section{Research Objectives}

Based on the background and formulation of the research problem, this study aims as follows:

1. To analyze the effect of partial work motivation on the performance of Indomaretstore employees 
Surabaya.

2. To analyze the partial influence of work discipline on Indomaretstore performance employees Surabaya.

3. To analyze the influence partial organizational culture on the performance of Indomaretstore employees Surabaya.

4. To analyze the simultaneous effect of work motivation, work discipline and organizational culture on the performance of Indomaret Surabaya store employees

\section{LITERATURE REVIEW}

\section{Work Motivation}

According to Henry Simamora understanding motivation is a function of individual expectations that certain efforts will produce a level performance which in turn will producerewards or results the desired.

\section{Discipline Work}

Discipline is defined as management activities to carry out organizational standards (T. Hani Handoko, 1996). According to discipline is a mental attitude that is reflected in the actions or behavior of individuals, groups, or society

\section{Organizational Culture}

culture can also be simply interpreted how everything is resolved in that place (Deal \& Kennedy, 2000

\section{Employee Performance}

Performance is the work of behavior (Armstrong, 1999: 15) Understanding this performance associates work outcomes with behavior

\section{Previous}

(Novelisa P. Budiman's,1996), (Ivonne S. Saerang,2006), and (Greis M. Sendow,2008) on the significant influence ofmotivation workand work discipline on employee performance at PT. HASJRAT ABADI TENDEAN MANADO The results of (Enrico Maramis's,1998) research on organizational culture and work motivation have a significant effect on the performance of employees at the Manado Branch of Bank Tabungan Negara (PERSERO), the results of Jeremiaresearch Tuage's, Bernhard Tewal and Yantje Uhing, about work motivation the performance of employees at PT. Astragraphia tbk.

\section{Conceptual Framework}

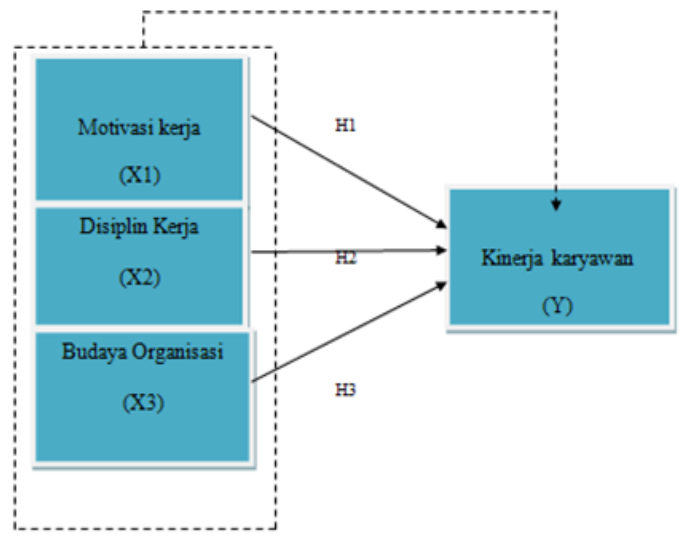

Figure 1 Thinking Framework

\section{Hypothesis:}

H1: Work motivation has a partial significant effect on employee performance 
H2: Work discipline has partial and significant effect on employee performance

H3: Organizational Culture has a partial significant effect on employee performance

H4: Work motivation, work discipline and culture organizations have a significant effect simultaneously on employee performance

\section{RESEARCH METHODS}

\section{Types}

Data used in this study is primary data. Primary data is a source of data researchobtained directly from the original source, namely employees of Indomaret shop, South Surabaya. To obtain data that researchers use questionnaires. The questionnaire is a data collection tool in the form of a list of written questions to obtain the score from the number of respondents.

\section{Data}

Sources The data sources used in this study are primary data and secondary data. Primary data is obtained through research questionnaires distributed to employees of Indomaret stores in South Surabaya.

\section{Population}

Population is a generalization area consisting of objects or subjects that havequalities and certaincharacteristics that are appointed by researchers who are studied and then added conclusions (Sugiyono, 2011: 80). The number is the population that will be used as data in the study are 62 employees at the Indomaret Store in Surabaya.

\section{Variable Measurement}

1. Work motivation is a skill in directing or controlling and moving a person to take action on desired behavior based on set goals to achieve certain goals. According to Wibowo (2011: 162)

2. Work discipline is not solely obedient and obedient to regulations regarding working hours only, for example coming and going home according to schedule not absent when working, and not lurking in time

3. Innovation and courage to take risks The extent to which employees are encouraged to be innovative and dare to take risks

4. That performance is basically what employees do or don't do.

\section{Test Validity}

Validity according to Sugiyono (2016: 177) shows the degree of accuracy between the actual data that occurs on the object and the data collected by the researcher to look for the validity of an item, we correlate the item score with the total items.

\section{Test Reliability}

Test is the extent to which the results of measurements using the same object will produce the same data (Sugiyono, 2012: 177). Reality test of the questionnaire in the study used the split half item method divided into two groups, namely the odd number of items and even group items. Then each group score was added to each item so as to produce a total score.

\section{Classical Assumptions}

Test is a test conducted to determine whether the regression model made can be used as a good predictor. The Classical Assumption Test to be carried out is the Multicollinearity Test, Heterocystaticity Test and Normality Test.

\section{Multicollinearity Test}

According to Ghozali (2012: 105) the multicollinearity test aims to test whether the regression model found a correlation between independent variables. A good regression model should not have a correlation between the independent variables. Multicollinearity can be detected by looking at tolerance values and the variance inflation factor (VIF).

\section{Heteroscedasticity Test}


According to Ghozali (2012: 139) the purpose of heteroscedasticity test is to test whether in themodel regressionvariance occurs from one study to the research. The way to testdata heteroscedasticityis to see the presence or absence of a certain pattern on the scatterplot chart between SRESID and ZPRED, where the $\mathrm{Y}$ axis is $\mathrm{Y}$ predicted, and the $\mathrm{X}$ axis is residual ( $\mathrm{Y}$ prediction - $\mathrm{Y}$ actually) which has been standardized

\section{Normality Test}

by Ghozali's( 2012: 160) defines that the normality test aims to test whether in the regression model, independent variables and dependent variables both have normal data distribution or not.

\section{Test of Multiple Linear Regression Multiple}

Linear regression analysis in this study was conducted to determine the relationship between variables

$$
\mathrm{Y}=\mathrm{a}+\mathrm{b} 1 \mathrm{X} 1+\mathrm{b} 2 \times 2+\mathrm{b} 3 \times 3+e
$$

Description:

Y=Employeeperformance

$\mathrm{a}=$ Value Constant

b1, b2, b3 = Variable Coefficient

$\mathrm{X} 1=$ Motivation Work

$\mathrm{X} 2=$ Work Discipline

$\mathrm{X} 3$ = Organizational Culture

$\mathrm{e}=$ Error term

\section{RESEARCH RESULTS AND DISCUSSION}

\section{Test Validity}

An instrument is said to be valid if it is able to measure what it wants to measure or can reveal data from variables that are properly examined.

Table 1 Data validity test results

\begin{tabular}{|c|c|c|c|c|}
\hline \multicolumn{5}{|c|}{ Item-Total Statistics } \\
\hline Variable & Item & $\begin{array}{c}\text { Corrected Item- } \\
\text { Total Correlation }\end{array}$ & R tabel & Keterangan \\
\hline Work Motivation & X1.1 & 0,462 & 0.2500 & Valid \\
& X1.2 & 0,612 & 0.2500 & Valid \\
& X1.3 & 0,676 & 0.2500 & Valid \\
& X1.4 & 0,575 & 0.2500 & Valid \\
& X1.5 & 0,459 & 0.2500 & Valid \\
& X1.6 & 0,655 & 0.2500 & Valid \\
& X1.7 & 0,502 & 0.2500 & Valid \\
& X1.8 & 0,574 & 0.2500 & Valid \\
& X1.9 & 0,432 & 0.2500 & Valid \\
\hline Work Discipline & X2.1 & 0,538 & 0.2500 & Valid \\
& X2.2 & 0,515 & 0.2500 & Valid \\
& X2.3 & 0,388 & 0.2500 & Valid \\
& X2.4 & 0,410 & 0.2500 & Valid \\
& X2.5 & 0,544 & 0.2500 & Valid \\
\hline Organizational Culture & X3.1 & 0,600 & 0.2500 & Valid \\
& X3.2 & 0,608 & 0.2500 & Valid \\
& X3.3 & 0,786 & 0.2500 & Valid \\
& X3.4 & 0,715 & 0.2500 & Valid \\
& X3.5 & 0,597 & 0.2500 & Valid \\
& X3.6 & 0,792 & 0.2500 & Valid \\
& X3.7 & 0,669 & 0.2500 & Valid \\
& X3.8 & 0,701 & 0.2500 & Valid \\
& X3.9 & 0,642 & 0.2500 & Valid \\
& X3.10 & 0,620 & 0.2500 & Valid \\
\hline & Y1.1 & 0,600 & 0.2500 & Valid \\
& Y1.2 & 0,608 & 0.2500 & Valid
\end{tabular}


Based on table 4.9 can be seen the value of $r$ the count is greater than $r$ table $(0.2500)$ which means that each indicator variable is valid, so it can be concluded that these indicators can be used to measure research variables.

\section{Reliability Test}

Table 2 Test Reliability

\begin{tabular}{|c|c|c|}
\hline Variabel & $\begin{array}{c}\text { Cronbach's Alpha if Item } \\
\text { Deleted }\end{array}$ & Description of \\
\hline Work Motivation (X1) & 0,832 & Reliability \\
Work Discipline (X2) & 0,789 & Reliability \\
Organizational Culture (X3) & 0,886 & Reliability \\
Employee Performance (Y1) & 0,773 & Reliability \\
\hline
\end{tabular}

Reliability testing technique is to use the alpha reliability coefficient value. Thecriteria decisionis if the value of the alpha reliability coefficient is greater than 0.6 then the variable is reliable. From Table 2 it is known that alpha cronbach's value for all variables greater than 0.6. From the provisions mentioned earlier, all variables used for research are reliable.

\section{Classical Assumption}

Test Normality

Test This test is identified by graph analysis, in the normal graph of the plot the points must spread with diagonal lines

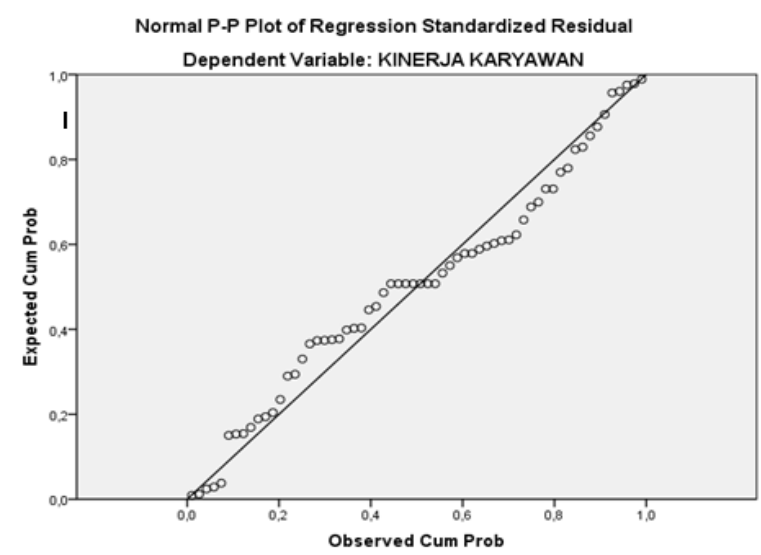

Figure 1 Normality Test

The results of the test show that the points are not far from the diagonal line. This means that the regression model is normal. While testing the normal distribution using statistical calculations using the following Kolmogorov smirnov:

Table 3 Test of Kolmogorov-smirnov

\begin{tabular}{|c|c|c|}
\hline \multicolumn{3}{|c|}{ One-Sample Kolmogorov-Smirnov Test } \\
\hline & & Unstandardized Residual \\
\hline $\mathrm{N}$ & & 62 \\
\hline Normal Parametersa,b & Mean &, 0000000 \\
& Std. &, 79034740
\end{tabular}




\begin{tabular}{|c|c|c|} 
& Deviation & \\
Absolute &, 104 \\
Positive &, 100 \\
& Negative &,- 104 \\
Kolmogorov-Smirnov Z & &, 822 \\
Asymp. Sig. (2-tailed) & &, 509 \\
\hline
\end{tabular}

In the table of the results of testing normal distribution with the Kolmogorov Smimov method to strengthen testing

with graphs obtained a significance value of $0.509>0.05$, so the regression model is normally distributed.

\section{Multicollinearity Test}

Multicollinearity test aims to test whether the regression model is found to have a correlation between independent variables

Table 4 Multicollinearity Test

\begin{tabular}{|c|c|c|c|}
\hline \multicolumn{4}{|c|}{ Coefficients $^{\mathrm{a}}$} \\
\hline \multirow{2}{*}{\multicolumn{2}{|c|}{ Model }} & $\begin{array}{c}\text { Collinearity } \\
\text { Statistics }\end{array}$ & \\
\hline & & Tolerance & VIF \\
\hline \multirow[t]{4}{*}{1} & (Constant) & & \\
\hline & MOTIVATIONX1 & ,486 & 2,056 \\
\hline & DISCIPLINEX2 & ,640 & 1,562 \\
\hline & $\begin{array}{l}\text { ORGANIZATIONAL } \\
\text { CULTUREX3 }\end{array}$ &, 521 & 1,919 \\
\hline
\end{tabular}

Based on table 15 above, it can be explained that the questionnaire research data used can be used for further testing due to multicollinearity test results this, the research data has a VIF value $<10$ and tolerance value less than

\section{Heterocedasticity}

Test Heteroscedasticity aims to test whether in the regression modelinequalities occur variancefrom residuals to one observation to another observation,then called Homoscedasticity and if it is called Heteroscedasticity

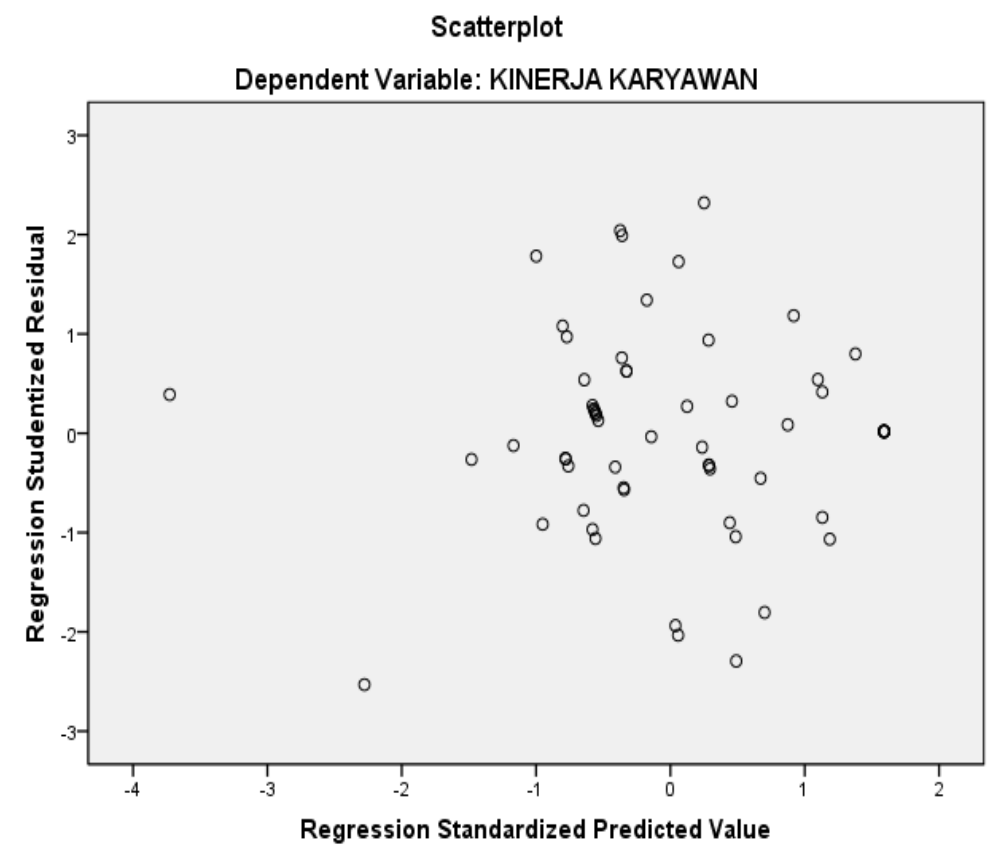


Figure 2 Scatterplot

Table 4

\begin{tabular}{|c|c|c|c|c|c|c|}
\hline & \multirow[t]{2}{*}{ Model } & \multicolumn{2}{|c|}{ Unstandardized Coefficients } & \multirow{2}{*}{$\begin{array}{c}\begin{array}{c}\text { Standardized } \\
\text { Coefficients }\end{array} \\
\text { Beta } \\
\end{array}$} & \multirow[t]{2}{*}{$\mathbf{t}$} & \multirow[t]{2}{*}{ Sig. } \\
\hline & & $\mathrm{B}$ & Std. Error & & & \\
\hline \multirow[t]{4}{*}{1} & (Constant) & 1,851 & 0,828 & & 2,234 & 0,029 \\
\hline & MOTIVATIONX1 & 0,017 & 0,027 & 0,111 & 0,614 & 0,541 \\
\hline & DISCIPLINEX2 & $-0,076$ & 0,039 & $-0,306$ & $-1,950$ & 0,056 \\
\hline & $\begin{array}{l}\text { ORGANIZATION } \\
\text { CULTUREX3 }\end{array}$ & $-0,008$ & 0,020 & $-0,069$ & $-0,398$ & 0,692 \\
\hline
\end{tabular}

Based on the results of heteroscedasticity test seen drawn that there are no clear patterns and points spread above and below zero on the $\mathrm{Y}$ axis. From the picture above, it can be concludedfree that heteroscedasticity isso that regression models can be used to predict employee performance levels based onvariables independent or independentnamely work motivation, work discipline and organizational culture

\section{Testing Hypothesis \\ T-Test}

Table 5 T Test

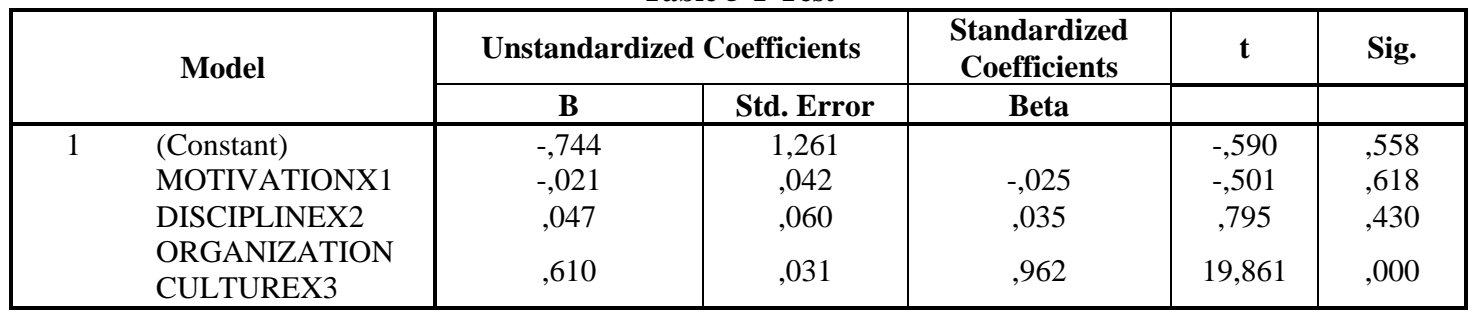

\section{Work Motivation Variables}

Ho: $b 1 \leq 0$ : Work Motivation does not have a significant positive effect on employee performance

Ha: b1>0: Work Motivation has a significant positive effect on employee performance

$\mathrm{T}$ test results for $\mathrm{X} 1$ variable (Work Motivation) obtained $\mathrm{t}$ count $=-0,501$ withlevel significanceof 0.05 . By using a significance limit of 0.05 , the $t$ table is equal to 1.670 . This means that $t$ count $>t$ table, which means that $\mathrm{Ho}$ is rejected and $\mathrm{Ha}$ is accepted. Thus, the first hypothesis can be accepted. The direction of the positive regression coefficient means that Work Motivation has a significant positive effect on employee performance. In other words it can be concluded that Work Motivation is getting better, it will accelerate employee performance.

\section{Work Discipline Variable}

Ho: b2 $\leq 0$ : Work Discipline does not have a significant positive effect onemployee performance Ha: b2> 0: Work Discipline has a significant positive effect on employee performance

$\mathrm{X} 2$ variable $\mathrm{t}$ (Work Discipline) $\mathrm{t}$ value $=0.795$ with significance level 0.05 . By using a significance limit of $0.05, \mathrm{t}$ table is obtained at 1.670. This means $\mathrm{t}$ count $>\mathrm{t}$ table, which means Ho is rejected and Ha is accepted. Thus, the second hypothesis can be accepted. The direction of thecoefficient positive regressionmeans that Work Discipline has a significant positive influence onperformance employee.

\section{Organizational Culture Variables}

Ho: b3 $\leq$ 0: Organizational Culture does not have a significant positive effect on employee performance Ha: b3> 0: Organizational Culture has a significant positive effect on employee performance

The results of $\mathrm{t}$ test $\mathrm{X} 3$ variable (Organizational Culture) obtained $\mathrm{t}$ count $=19,861$ with alevel significance0.05. By using a significance limit of $0.05, \mathrm{t}$ table is obtained at 1.670. This means $t$ count $>\mathrm{t}$ table, which means Ho is rejected and $\mathrm{Ha}$ is accepted. Thus the third hypothesis can be accepted. The direction of the positive regression coefficient means that Work Organization Culture has a significant positive influence on 
employee performance. In other words it can be concluded that Organizational Culture is increasingly guaranteed, will increase employee performance.

F-Test

Table 5 Test $F$

\begin{tabular}{|c|c|c|c|c|c|c|}
\hline \multicolumn{8}{|c|}{ ANOVA $^{\mathbf{b}}$} \\
\hline \multirow{2}{*}{ Model } & Rum of & Df & $\begin{array}{c}\text { Mean } \\
\text { Square }\end{array}$ & F & Sig. \\
\hline & Regression & 499,138 & 3 & 166,379 & 253,257 &, 000 \\
& Residual & 38,104 & 58 &, 657 & & \\
& Total & 537,242 & 61 & & & \\
\hline
\end{tabular}

Simultaneous / simultaneous significance test ( $\mathrm{F}$ statistic test) produces a calculated $\mathrm{F}$ value of 253,257 . At the free degree $1(\mathrm{df} 1)=$ number of variables $-1=4-1=3$, and free degrees $3(\mathrm{df} 3)=\mathrm{nkl}=62-3-1=$, where $\mathrm{n}=$ number of samples, $\mathrm{k}=$ number of independent variables, value of $\mathrm{F}$ table at the level of significance of 0.05 confidence is 3.15 thus $\mathrm{F}$ count $253.257>\mathrm{F}$ table $=3.15$ with a significance level of 0.000 . Because the probability of synergy is much smaller than sig $<0.05$, the regression model can be used to predict the performance of Indomaret employees in southern Surabaya, or it can be said that Work Motivation (X1), Work Discipline (X2), Organizational Culture (X3) are jointly influential on employee performance in Indomaret South Surabaya

\section{DISCUSSION}

\section{Effect of Work Motivation on Employee Performance}

The first hypothesis proposed states that Work Motivation significantly influences employee performance, partially this has been proven by the results of the $t$ test value of 0.501 . This is rational because it is in accordance with the responses of respondents regarding Work Motivation. In response, respondents stated that the Work Motivation given by the company was in accordance with their expectations. The fact that there is a significant influence of Work Motivation on performance can be clarified by the results of multiple linear regression analysis. Multiple linear regression analysis also indicates that each increase in oneunit Work Facilitywill increase performance by 0.025 . Means the higher / greater Work Motivation, the better / higher employee performance.

\section{Effect of Workon Employee Performance}

DisciplineThe second hypothesis proposed states that Work Discipline significantly influences performance, partially this has been proven by the value of the test results t0,795 This is rational because it is in accordance with the respondent's responses regarding the Award. In his response the respondents stated that the Award Program implemented by the company was able to guarantee the spirit of work for employees. The reality is that there is a significant influence. Award for performance is clarified by the results of multip leregression linearanalysis. Multiple linear regression analysis also indicates that for each increase in one unit of appreciation the performance will also increase by 0.035. It means that the higher / bigger the award, the better / higher the employee's performance.

\section{The Influence of the Work Environment on Employee Performance}

The third hypothesis proposed states that the work environment has a significant effect on performance, partially this has been proven by the results of $t$ test value 19.861 This is rational because it is in accordance with respondents' responses regarding job security. In his response the respondent stated that "Job security programs implemented by the company are able to guarantee the comfort and calm of working for employees. The fact is that there is a significant influence on the work environment on performance, clarified by the results of multiple linear regression analysis. Multiple linear regression analysis also indicates that every increase in one unit of the work environment, the performance will also increase by 0.962 . Means that the higher theenvironment working, the better / higher the employee's performance.

\section{Effect of Work Motivation, Work Discipline, and Organizational Culture on Employee Performance}


The fourth hypothesis states Work Motivation, Work Discipline, and Organizational Culture have aeffect significanton performance. This is evident from the results of the questionnaire, the respondents stated that the company has provided adequate Work Motivation, Work Discipline and Organizational Culture for them. Based on the F test, it can be seen that Work Motivation, Work Discipline, and Organizational Culture together have a positive and significant effect on improving employee performance. This is seen from the value of Fcount> Ftable which is 253.257> 3.15, meaning that the higher / greater Work Motivation, Work Discipline and Organizational Culture simultaneously, the better / higher the employee's performance. This is also evident from the responses of respondents regarding Work Motivation, Work Discipline programs and Organizational Culture given by the company that Work Motivation, Work Dissipli and Organizational Culture simultaneously have a significant effect on employee performance.

\section{CONCLUSION}

1. Job motivation has a positive and significant effect on employee performance, this means that if Work Motivation increases it will improve employee performance.

2. Work Discipline has a positive and significant effect on employee performance, this means that if Work Discipline increases it will improve employee performance.

3. Organizational Culture has a positive and significant effect on employee performance, this means that if theCulture Organizationalincreases it will improve employee performance.

\section{SUGGESTIONS}

1. For Companies

Work Motivation, Work Discipline and Organizational Culture proved to have an effect on employee performance so the company should provide work assignments and continue to provide good motivation to establishcooperation good between subordinates and superiors.

2. For Employees

It is better to pay attention to things that can improve performance to further improve thesystem performanceeven better, so that it can provide the best values for the Indoaret Store in Surabaya south

3. For Institutions of the Faculty of Economics

For institutions of economic faculties should add knowledge and insight that can foster critical thinking in conducting research on performance, work motivation, work discipline, and culture of company organizations or others related to economic management.

4. For Researchers

For further research you should add other variables that can affect performance employeesuch as bonuses, awards and communication so that you can compare them in research.

\section{REFERENCES}

Abdullah, M. M. (2014). Employee Performance Management and Evaluation. In the National Library of Indonesia. Alex. S Nitisemito. 1984. Corporate Learning. Jakarta: Ghalia Indonesia.

Ardansyah, 2014. Supervision, Work Discipline, and Staff Performance of Central Lampung Regency Statistics Agency ". jurnalmanelola.petra.ac.id accessed on July 112015

Arifin, H. M. (2015). The Influence of Competence, Motivation, and Organizational Culture to High School Teacher Job Satisfaction and Performance. 8 (1), 38-45. https://doi.org/10.5539/ies.v8n1p38

Azis Fathoni et al. 2016. Effect of Motivation and Work Discipline on Employee Performance at the Semarang Civil Service Police Unit Office. Journal of Management Vol. 2, No. 2.

Dar, B., \& Uju, S. (2013). The Influence of Motivation on Employees' Performance: A Study of Some Selected Firms in Anambra State. 2 (7), 134-151.

Ghozali,Imam.2012.Aplikasi Analisis Multivariate dengan Program IBM SPSS.Yogyakarta:Universitas Diponegoro Handoko, T. Hani "Personnel management and human resources / T. Hani Handoko" (1996)

Hm, M., \& Province, G. (2018). Empirical Study of the Effect of Spiritual Intelligence on Organizational Citizenship Behavior and Performance: A Literature Review. (March).

Khairiyah, 2013. Effect of Job Satisfaction, Leadership Style and Work Motivation on Employee Performance at PT Nutricia Indonesia Sejahtera. Proceeding PESAT Bandung. Vol 5 
Norton, T. A., Parker, S. L., Zacher, H., \& Ashkanasy, M. N. (2015). Employee Green Behavior: A Theoretical Framework, Multilevel Review, and Future Research Agenda. https://doi.org/10.1177/1086026615575773

On, P., Pln, P. T., Wilayah, P., Area, S., Mandey, S. L., Economy, F., \& Management, J. (n.d.). No Title. 2 (3), $1592-1602$.

Priyono, P., \& Darma, U. B. (2016). Human Resource Management Book (2).

Rashid, Z. A., \& Sambasivan, M. (2003). The influence of corporate culture and organizational commitment on performance. (1999). https://doi.org/10.1108/02621710310487873

Saad, M. (2013). Impact of Organizational Culture on Employee Performance. 168-175.

Sajangbati, I. A. S., Management, J., Sam, U., \& Manado, R. (n.d.). Issue 2303-1174. 1 (4), 667-678.

Sugiyono.(2016).Metode Penelitian Kuantitatif, Kualitatif dan R\&D. Bandung:PT Alfabet.

Xenikou, A., \& Simosi, M. (2006). Organizational culture and transformational leadership as predictors of business unit performance. (1985), 566-579. https://doi.org/10.1108/02683940610684409 